\title{
A qualitative investigation of influencing factors for anxiety and depression in patients with advanced cancer after multiline treatment failure
}

Xujing Yang

Wenzhou Medical University First Affiliated Hospital

Qingqing Xie

Wenzhou Medical University First Affiliated Hospital

\section{Caixia Sun}

Wenzhou Medical University First Affiliated Hospital

Zhenghua Fei ( $040077455 @ q q . c o m$ )

Wenzhou Medical University First Affiliated Hospital https://orcid.org/0000-0002-5488-8901

\section{Research article}

Keywords: Anxiety, Depression, Cancer, Immunotherapy

Posted Date: August 17th, 2020

DOI: https://doi.org/10.21203/rs.3.rs-46056/v1

License: (c) (i) This work is licensed under a Creative Commons Attribution 4.0 International License. Read Full License 


\section{Abstract}

Background: To investigate the anxiety and depression of patients with advanced cancer who received immunotherapy using programmed death-1 or programmed death-ligand 1 after multiline treatment failure, to explore the influencing factors, and to provide reference for clinical medical staff and psychological support for patients.

Methods: The Hospital Anxiety and Depression Scale was used to calculate the anxiety and depression scores before and after 1, 2 and 3 courses of treatment, respectively. The patients with anxiety and depression were counted. Purposive sampling was used to conduct face-to-face semi-structured interviews with 21 patients to find out the reasons. The obtained data were analyzed and collated using the Colaizzi's phenomenological method.

Results: Before and after 1, 2 and 3 courses of treatment, $18.26 \%, 23.0 \%, 50 \%$ and $54 \%$ of patients suffered from anxiety and depression, respectively. Four related factors, i.e. low expectations for immunotherapy, lack of timely information after treatment, lack of awareness of treatment and drugs, and lack of family and social support, were extracted with the sampling survey. The proportion of patients with anxiety and depression during immunotherapy kept increasing.

Conclusion: The anxiety and depression of patients with advanced cancer who receive immunotherapy after multiline treatment failure are aggravated along with treatment. Patients need to be given humane care and emotional support from their families, society and medical staff. Nursing staff should adopt personalized measures to meet the psychological needs of patients, and a targeted and complete nursing system should be established to extend the life span and to improve the quality of life.

Trial registration: ChiCTR, ChiCTR1800015942. Registered 1 May 2018, http://www.chictr.org.cn/showproj.aspx? proj $=26476$

\section{Background}

Malignant tumors have seriously threatened human health and increased the economic burdens of patients with cancers, as a major public health problem worldwide, their families and society (1). In China, patients who die of malignant tumors account for $23.91 \%$ of all death cases (1). The incidence and mortality rates of malignant tumors have continued to increase in the past decades, and the annual medical expenses have exceeded 35 billion Dollar (2). Therefore, the treatment of advanced malignant tumors is challenging and urgent worldwide (3). In recent years, immunotherapy, especially immune checkpoint inhibitor-related therapy represented by programmed death-1 (PD-1)/programmed death-ligand 1 (PD-L1), has been successfully employed to treat melanoma (4), non-small cell lung cancer (5), kidney cancer (6), bladder cancer (7), and other advanced tumors (8). Patients with cancer are prone to anxiety and depression, with an average incidence rate of $24 \%(9,10)$. As a new strategy, immunotherapy is still in the clinical trial stage with elusive long-term effects and complications, and the psychological status of patients receiving this treatment is evidently different from that of ordinary ones. Thereby motivated, we herein explored factors related to exacerbate anxiety and depression in these patients, aiming to provide valuable evidence for clinical diagnosis, treatment and nursing.

\section{Methods}

\section{Samples}

A consecutive series of 126 patients attending a range of outpatient clinics in The First Affiliated Hospital of Wenzhou Medical University (Wenzhou, China), who have failed multiple immunotherapies, were recruited between January and December 2019. Recruit patients who failed multiple immunotherapies have signed informed consent. All the findings were confirmed through more than two medical staffs (one of them was a psychologist) by means of patient communication. This study was approved by the Regional Ethics Committee of the First Affiliated Hospital of Wenzhou Medical University 
(Code: ChiCTR1800015942). All procedures performed in the study were being carried out in accordance with the principles of the Declaration of Helsinki. Written informed consent was obtained from each patient before treatment.

\section{Inclusion criteria}

1) Patients who received immunotherapy after multiline treatment failure; 2) those without speech/communication impairment or mental retardation, and with ability to complete the scale; 3) voluntary interviewees; 4) self-care of medication costs, without participating in other clinical trials.

\section{Survey contents and methods}

The medical staff recorded the baseline clinical data of included patients, including name, gender, age, past medical history, current medical history, occupation, family members and economic income. Anxiety and depression were assessed using the Hospital Anxiety And Depression Scale (HADS) (11). Face-to-face semi-structured interviews were conducted for objective sampling by purpose sampling methodology. The sample size was determined according to the data saturation principle, i.e. no important or new topics appeared (12). HADS is a self-administered rating scale with 14 items which are divided into 2 subscales (measuring anxiety and depression respectively), each containing seven items. Each item was rated on a four-point scale from 0 to 3 points, with a maximum subscale of 21 and an overall distress score of 0-42 points, and a higher score indicates more severe distress. A score of $\geq 7$ corresponds to anxiety or depression. Patients with both score of $\geq 7$ points were included in an anxiety and depression group $(13,14)$. Before interview, we call the patient to make an appointment. The patient is interviewed or postponed according to their physical and mental conditions. At the beginning of the interview, the patients were explained about the purpose of this study, the principle of confidentiality, and the need for full recording. The interview was conducted in a classroom of our department, which was equipped with a small round table and a sofa. The environment was quiet and comfortable. Only the patient or accompanied by the patient's close family was mentally well and stable. The interview time was controlled within $40 \sim 60$ min. During interview, the medical staff kept the theme, listened carefully and asked questions in time. Questions asked about interviewing patients mainly include: 1) You have undergone surgery or chemotherapy, radiotherapy, targeted therapy, and now choose P-1, can you tell me your treatment experience and story? 2) Do you have any difficulties and stress in receiving immunotherapy? 3) Are you confident in immunotherapy? 4) Have you heard of this medicine before? How make you understand it? 5) Have you actively reported adverse reactions during immunotherapy? 6) Do you think your family gives you the greatest support?

\section{Analysis information}

Colaizzi's method was utilized for analysis. 1) The data were read carefully; 2) important statements were extracted; 3 ) recurring views were codified; 4) coded views were gathered; 5) a detailed and no omission description was written; 6) similar views were identified. Through detailed analysis and reasoning of the materials, the common parts were summarized into the theme and elements of cost research.

\section{Results}

\section{Characteristics of samples}

All the 126 sent out questionnaires were valid (recovery: 100\%). After 1 and 2 courses of treatment, all 126 questionnaires were valid (recovery: 100\%). Before the third course of treatment, 9 patients stopped immunotherapy, so 117 questionnaires were distributed after 3 courses (recovery: 100\%). The survey results of HADS are shown in Table 1, and the clinical characteristics of 21 patients (14 male, 7 female) included in the sample study are listed in Table 2. 
Table 1

Survey results of HADS

\begin{tabular}{|llll|}
\hline Time & Number of questionnaires & Number of patients with anxiety and depression & Proportion (\%) \\
\hline Before use & 126 & 23 & $18.3 \%$ \\
\hline After 1 course & 126 & 29 & $23.0 \%$ \\
\hline After 2 courses & 126 & 63 & $50.0 \%$ \\
\hline After 3 courses & 117 & 63 & $54.0 \%$ \\
\hline
\end{tabular}


Table 2

Clinical characteristics of patients

\begin{tabular}{|c|c|c|c|c|c|c|c|c|}
\hline NO. & Education & $\begin{array}{l}\text { Marital } \\
\text { status }\end{array}$ & Occupation & Cancer site & $\begin{array}{l}\text { Drug } \\
\text { type }\end{array}$ & $\begin{array}{l}\text { Medication } \\
\text { times }\end{array}$ & $\begin{array}{l}\text { Know about } \\
\text { immunotherapy }\end{array}$ & $\begin{array}{l}\text { Know the } \\
\text { disease } \\
\text { treatment }\end{array}$ \\
\hline 01 & $\begin{array}{l}\text { College } \\
\text { and } \\
\text { above }\end{array}$ & Married & Retiree & $\begin{array}{l}\text { Mouth and } \\
\text { nasopharynx }\end{array}$ & PD-1 & 24 & YES & NO \\
\hline 02 & $\begin{array}{l}\text { High } \\
\text { school }\end{array}$ & Married & Businessman & $\begin{array}{l}\text { Mouth and } \\
\text { nasopharynx }\end{array}$ & PD-1 & 8 & NO & NO \\
\hline 03 & $\begin{array}{l}\text { College } \\
\text { and } \\
\text { above }\end{array}$ & Unmarried & Businessman & $\begin{array}{l}\text { Mouth and } \\
\text { nasopharynx }\end{array}$ & PD-1 & 4 & YES & NO \\
\hline 04 & $\begin{array}{l}\text { Below } \\
\text { junior } \\
\text { high } \\
\text { school }\end{array}$ & Married & $\begin{array}{l}\text { Worker or } \\
\text { farmer }\end{array}$ & Gynecology & PD-1 & 8 & NO & NO \\
\hline 05 & $\begin{array}{l}\text { Junior } \\
\text { high } \\
\text { school }\end{array}$ & Married & $\begin{array}{l}\text { Worker or } \\
\text { farmer }\end{array}$ & $\begin{array}{l}\text { Mouth and } \\
\text { nasopharynx }\end{array}$ & $\begin{array}{l}\text { PD- } \\
\text { L1 }\end{array}$ & 6 & NO & YES \\
\hline 06 & $\begin{array}{l}\text { College } \\
\text { and } \\
\text { above }\end{array}$ & Married & $\begin{array}{l}\text { Civil servant } \\
\text { or lawyer }\end{array}$ & Breast & PD-1 & 3 & YES & YES \\
\hline 07 & $\begin{array}{l}\text { Junior } \\
\text { high } \\
\text { school }\end{array}$ & Married & Businessman & Melanoma & PD-1 & 10 & NO & YES \\
\hline 08 & $\begin{array}{l}\text { Below } \\
\text { junior } \\
\text { high } \\
\text { school }\end{array}$ & Married & $\begin{array}{l}\text { Worker or } \\
\text { farmer }\end{array}$ & Lung & PD-1 & 4 & NO & NO \\
\hline 09 & $\begin{array}{l}\text { College } \\
\text { and } \\
\text { above }\end{array}$ & Married & $\begin{array}{l}\text { Civil servant } \\
\text { or lawyer }\end{array}$ & Lung & PD-1 & 3 & YES & YES \\
\hline 10 & $\begin{array}{l}\text { Junior } \\
\text { high } \\
\text { school }\end{array}$ & Married & Businessman & Stomach & $\begin{array}{l}\text { PD- } \\
\text { L1 }\end{array}$ & 12 & YES & NO \\
\hline 11 & $\begin{array}{l}\text { Junior } \\
\text { high } \\
\text { school }\end{array}$ & Married & Businessman & Gynecology & PD-1 & 10 & YES & YES \\
\hline 12 & $\begin{array}{l}\text { High } \\
\text { school }\end{array}$ & Married & Businessman & $\begin{array}{l}\text { Mouth and } \\
\text { nasopharynx }\end{array}$ & PD-1 & 3 & NO & NO \\
\hline 13 & $\begin{array}{l}\text { Junior } \\
\text { high } \\
\text { school }\end{array}$ & Married & $\begin{array}{l}\text { Worker or } \\
\text { farmer }\end{array}$ & Breast & PD-1 & 5 & NO & NO \\
\hline 14 & $\begin{array}{l}\text { High } \\
\text { school }\end{array}$ & Married & $\begin{array}{l}\text { Worker or } \\
\text { farmer }\end{array}$ & Lung & PD-1 & 3 & NO & YES \\
\hline 15 & $\begin{array}{l}\text { Junior } \\
\text { high } \\
\text { school }\end{array}$ & Married & $\begin{array}{l}\text { Worker or } \\
\text { farmer }\end{array}$ & Stomach & PD-1 & 4 & NO & NO \\
\hline 16 & $\begin{array}{l}\text { High } \\
\text { school }\end{array}$ & Married & Businessman & Lung & PD-1 & 10 & YES & YES \\
\hline
\end{tabular}




\begin{tabular}{|c|llllllll|}
\hline NO. & Education & $\begin{array}{l}\text { Marital } \\
\text { status }\end{array}$ & Occupation & Cancer site & $\begin{array}{c}\text { Drug } \\
\text { type }\end{array}$ & $\begin{array}{l}\text { Medication } \\
\text { times }\end{array}$ & $\begin{array}{l}\text { Know about } \\
\text { immunotherapy }\end{array}$ & $\begin{array}{c}\text { Know the } \\
\text { disease } \\
\text { treatment }\end{array}$ \\
\hline 17 & $\begin{array}{l}\text { Junior } \\
\text { high } \\
\text { school }\end{array}$ & Married & Retiree & $\begin{array}{l}\text { Mouth and } \\
\text { nasopharynx }\end{array}$ & PD-1 & 5 & NO & YES \\
\hline 18 & $\begin{array}{l}\text { College } \\
\text { and } \\
\text { above }\end{array}$ & Married & $\begin{array}{l}\text { Civil servant } \\
\text { or lawyer }\end{array}$ & Gynecology & PD-1 & 6 & YES & YES \\
\hline 19 & $\begin{array}{l}\text { Below } \\
\text { junior } \\
\text { high } \\
\text { school }\end{array}$ & Married & $\begin{array}{l}\text { Worker or } \\
\text { farmer }\end{array}$ & Gynecology & PD-1 & 11 & NO & NO \\
\hline 20 & $\begin{array}{l}\text { Junior } \\
\text { high } \\
\text { school }\end{array}$ & Married & $\begin{array}{l}\text { Worker or } \\
\text { farmer }\end{array}$ & Gynecology & PD-1 & 9 & NO & NO \\
\hline 21 & $\begin{array}{l}\text { High } \\
\text { school }\end{array}$ & Married & $\begin{array}{l}\text { Worker or } \\
\text { farmer }\end{array}$ & Colorectal & PD-1 & 5 & YES & YES \\
\hline
\end{tabular}

\section{Topic 1: Low expectations for immunotherapy}

\section{(1) Slow and unobvious effects of immunotherapy}

There are two main mechanisms for immunotherapy. PD-1 binds PD-L1 on the surface of tumor cells to inhibit the immune killing effect of human body, and tumors undergo immune escape via the PD-1/PD-L1 signaling pathway (15). PD-1/PD-L1 antibody blocks this signal pathway and enhances the sustained killing effect of cytotoxic T lymphocytes on tumor cells without transforming their essence, which can even deplete the cells. The effector cells restore the immune killing function, finally boosting the tumor-killing effect (16). Immunotherapy has the advantages of good tolerance and mild side effects, as an eligible option for patients with refractory cancer after multiline treatment failure. However, the effect of immunotherapy is slow and non-immediate. Patient A: "PD-1 is the once-in-a-century savior for us. It is unfortunate to have such a disease, but finally I have the chance to cure it after so many years (smiling). I have received 24 courses of treatment, but CT scan showed that the mass did not become larger or smaller. The doctor said that it was effective, but how come? The mass is not controlled, and I don't know how long I will undergo the treatment." Patient S: "PD-1 was bought by one of my family members in the United States. He told me that it had been on the market for a long time in the United States, as the most advanced antitumor drug currently. I have received 11 courses of treatment, but the effect is not obvious, and the mass remains." Patient G: "I have received 10 courses of treatment. Look at my thigh (groin), it's getting worse. Useless and lies, I'm hopeless (clenching the fist and knocking on the table)."Patient D: "The doctor said that tumor cells continuously metastasized and it was difficult to be controlled, so I received PD- $L 1$ therapy. I have received 8 courses, but I don't know whether it is effective. I feel hopeless. They said in the past that chemotherapy and targeted therapy may be effective, but also in vain (tears in eyes). I think I would not waste money on this drug if my son didn't ask our relatives to buy it in Hong Kong."

\section{(2) Poor self-cognitive health}

Patients with malignant tumors usually have long-term suffering. After multiline treatment such as surgery, radiotherapy, chemotherapy and targeted therapy, their physical fitness is weakened, accompanied by poor self-cognitive health. The medical staff asked if the patients wanted to know what they were doing. Patient M: "I don't want to know. It is impossible to cure this disease. I have taken this drug for 5 courses, but I feel worse every day. I will die before the Spring Festival. It is a waste of money."Patient U: "I have fecal incontinence and fatigue. The disease will kill me finally, and no drug is effective." 


\section{Topic 2: Lack of knowledge about immunotherapy}

In terms of access to information, patients believe more in the introduction of medical specialist and the practical experience of cured cases (12). Some patients search literature through the Internet or relatives (doctors) to get the latest progress in immunotherapy. Patient L: "I have heard that immunotherapy is the most effective new method for cancers, but I don't know if it is effective for this disease. After many courses of chemotherapy, the index levels did not drop. The doctor asked me to take PD-1, so I tried. There is no better way for me now."Patient H: "I have had lung cancer for 2 years, and also received surgery and chemotherapy. Cancer cells were found in bones this year. During the last treatment in Shanghai, I heard that the patient hospitalized next to me had the same disease and received several courses of PD-1 treatment, and the cancer was well controlled. I asked the doctor if I could try this drug. The doctor said that I could try if economic conditions permitted." Patient R: "I'm eager to know the effective rate of this drug for patients like me. I can't take it blindly. At least the doctor should detect one index every time after treatment to prove that it is effective." Therefore, medical staff should describe the current global situation of immunotherapy patiently in plain language. Well-educated patients should be provided as many ways of information inquiry as possible for their convenience. If the patient's close relatives are welleducated, it should also provide as many ways of information inquiry as possible to facilitate them. It is also necessary to give lectures about immunotherapy regularly, and to supply patients with multiple information sources.

\section{Topic 3: Unclear understanding of side effects of immunotherapy and insufficient clinical experience}

\section{(1) Inadequate clinical experience of medical staff}

At present, studies on immunotherapy are still far from mature, especially in the aspect of nursing which has not been included in daily training hitherto. Patient B: "After 2 courses of treatment, I feel stabbing pain in both lower extremities and fatigue sometimes. The nurses don't know why."Patient J: "The drug has not been used for a long time, so doctors hardly received training about it at school. Our family members even know more about the drug than many doctors. It is difficult for doctors to explain immunotherapy in detail. They also get confused at problems, let alone answer questions from patients."

\section{(2) Unclear understanding of side effects of immunotherapy}

The safety management of immunotherapy is of great significance. Patients must be informed of possible adverse reactions before immunotherapy, and doctors should evaluate and screen related risk factors. Patients are worried about the serious adverse reactions caused by PD-1 and the frustration of encountering withdrawal. Patient C: "Before the first course of treatment, I checked the information about the possible adverse reactions of PD-1 on the Internet. One relative, also a doctor, also helped me search for literature, so I was very worried about the drug. When I saw some erythema and felt itchy, I reported to the doctor immediately. The doctor confirmed that it was only a mosquito bite."Patient $\mathrm{H}$ : "During the first course of treatment, the nurse on duty failed to inject PD-1 three times due to the poor conditions of blood vessels, so the head nurse performed PICC for me. After I took off my tops, she found large areas of erythema on the chest, arms and back, and asked me if I felt itchy and why I didn't report to the doctor. I think I can tolerate the pain of chemotherapy before, not to mention such side effects. If the doctor knows, he will withdraw the therapy. Then I can do nothing but wait to die."

\section{Topic 4: Lack of adequate social and family support}

\section{Social insurance does not include immunotherapy}

Some anticancer drugs have been included in social insurance in China, but PD-1 remains excluded, thus rendering the drug unaffordable. Patient G: "I have taken the drug for six months. Re-examinations showed that the neck mass did not enlarge any more, and I don't feel painful now. The doctor says that tumor in the oral cavity has also been controlled, so PD-1 is effective for me. However, it is too expensive and not included in social insurance. My family has run out of money on this 
disease in the past few years, so I can do nothing but stop taking the drug (choking)." Patient E: "I have heard that PD-1 works well lung cancer. I have received 4 courses of treatment, but my family can't bear the expenses any longer. I raised some money through Shuidichou App the year before last, but this drug is so expensive and can't get reimbursed, so I ask the doctor if there are other cheaper drugs." Taken together, patients expect PD-1 or PD-L1 to be included in social insurance as soon as possible. "National Basic Medical Insurance, Industrial Injury Insurance and Maternity Insurance Drug Catalog" issued by the Chinese People's Government does not PD-1 or PD-L1. ( http://www.nhsa.gov.cn/art/2019/8/20/art_37_1666.html)

\section{Family members disagree and cannot provide adequate support}

Patients with malignant tumors obtain emotional support mostly from their spouses, children or parents, which also influences their thinking and behaviors. Patient $\mathrm{H}$ : "I'm taking K (PD-1), and my son tells me to receive 2 courses first. If it works, I will continue the treatment even at the cost of selling our house. If not, I will try other drugs. I will follow his suggestions." Patient E: "I noticed recently that my spouse often whispered to my father, sometimes in a loud voice. I'm sure they lack money again. so please persuade my father to stop buying this drug. I don't feel better. I just wish all my family members stay well together." In this study, three families had poor economic conditions, and they had a family meeting and decided to be aided by relatives and the Red Cross Society of China.

\section{Immunotherapy drugs are expensive, and some local hospitals do not buy them}

PD-1 is expensive due to patent cost, market monopoly and tariff on imported anticancer drugs. Hospitals in some areas of China do not have the drug and patients cannot receive immunotherapy. Patient G: "PD-1 is very effective for melanoma, which has been reported in the United States previously. The doctor said that the surgery was successful, but I needed to receive PD-1 for 1 year for radical treatment. As long as it can cure the disease, my family members will always support me. However, it is often difficult to buy this drug in China, so I can only ask others to buy it abroad. If I don't get the drug in time, the treatment will be delayed." Patient K: "Why PD-1 is not popular yet? I didn't get this drug this time, so the doctor asked me to try a domestic one, but I wonder if its efficacy is the same."

\section{Discussion}

Anxiety and depression, which are two different mental illnesses, often coexist in clinical practice. The incidence rate of anxiety and depression in cancer patients is $10 \%-30 \%$, and those of lung cancer patients is $11 \%-44 \%$ (17). The incidence of anxiety and depression in some young, advanced or individual types of cancer cases even exceeds 50\% (18). Patients with advanced tumors who receive immunotherapy after multiline treatment failure are different from other cancer cases. For example, the patients have long-term suffering, great threats to life, high early treatment cost, as well as low self-healing expectations and economic affordability. As a result, they are more vulnerable to emotional stress. After multiline treatment failure, the incidence rate of anxiety and depression was $54 \%$ after 3 courses of immunotherapy in this study. We attributed the anxiety and depression in patients receiving immunotherapy to the following reasons. 1) The acceptance of new drugs by patients is passive after several treatment failures; 2) young and educated patients are overly concerned about the effectiveness of immunotherapy. After long waiting and treatment processes, their anxiety and depression are aggravated; 3) immune-related adverse events are still largely unclear (19). If serious adverse reactions occur in clinical practice, doctors have to recommend discontinuation and symptomatic treatment; the long treatment process of patients with malignant tumors is bound to induce tremendous economic and mental stresses. As the treatment proceeded, the expenditure is not directly proportional to the therapeutic effect, thereby exacerbating the anxiety and depression of patients.

\section{Conclusion}


In summary, patients with advanced tumors after multiline treatment failure are susceptible to anxiety and depression during immunotherapy, who thus need timely test of emotional state and early intervention. Regardless, this study has limitations. Since the interviewees are from Wenzhou, Zhejiang Province and surrounding cities and counties, the results may differ from those of other regions in terms of economic basis and medical environment. Besides, the sample size is not large enough. The interview results may be different if cases are selected from other general hospitals or regions and the sample size is further increased.

\section{Abbreviations}

PD-1: programmed death-1; PD-L1: programmed death-ligand 1; HADS: Hospital Anxiety And Depression Scale

\section{Declarations}

\section{Ethics approval and consent to participate}

This study was approved by the Regional Ethics Committee of the First Affiliated Hospital of Wenzhou Medical University (Code: ChiCTR1800015942). All procedures performed in study was carried out in accordance with the principles of the Declaration of Helsinki. Written informed consent was obtained from each patient before treatment.

\section{Availability of data and materials}

The datasets used and/or analysed during the current study are available from the corresponding author on reasonable request.

\section{Consent for publication}

Not applicable

\section{Competing interests}

The authors declare that they have no competing interests.

\section{Funding}

Not applicable.

\section{Authors' contributions}

X.Y., C.S. and Z.F. conceived the study. X.Y. and C.S. collected the interview data and performed the script analysis. Q.X., Z.F. drafted the manuscript. All authors involved in the interpretation of data and manuscript revision. The author(s) read and approved the final manuscript.

\section{Acknowledgment}

The authors most honestly appreciate the patients for their participation in this study and all colleagues in the department of radiation and medical oncology of the First Affiliated Hospital of Wenzhou Medical University for their assistance in the present study.

\section{References}

1. Siegel RL, Miller KD, Jemal A. Cancer statistics. 2018. CA Cancer J Clin. 2018;68(1):7-30. 
2. Zheng RS, Sun KX, Zhang SW, Zeng HM, Zou XN, Chen R, et al. [Report of cancer epidemiology in China, 2015]. Zhonghua Zhong Liu Za Zhi. 2019;41(1):19-28.

3. Yang P, Shen B. Minimally invasive and precise treatment of malignant tumor. Chinese Journal of Clinical Oncology. 2016;11:452-6.

4. Robert C, Long GV, Brady B, Dutriaux C, Maio M, Mortier L, et al. Nivolumab in previously untreated melanoma without BRAF mutation. N Engl J Med. 2015;372(4):320-30.

5. Borghaei H, Paz-Ares L, Horn L, Spigel DR, Steins M, Ready NE, et al. Nivolumab versus Docetaxel in Advanced Nonsquamous Non-Small-Cell Lung Cancer. N Engl J Med. 2015;373(17):1627-39.

6. Motzer RJ, Rini BI, McDermott DF, Redman BG, Kuzel TM, Harrison MR, et al. Nivolumab for Metastatic Renal Cell Carcinoma: Results of a Randomized Phase II Trial. J Clin Oncol. 2015;33(13):1430-7.

7. Inman BA, Longo TA, Ramalingam S, Harrison MR. Atezolizumab. A PD-L1-Blocking Antibody for Bladder Cancer. Clin Cancer Res. 2017;23(8):1886-90.

8. Li HZ, Zhang YS, Zheng GY. Commentary on and Expectation of Tumor Immunotherapy. Medical Journal of Peking Union Medical College Hospital. 2018;9(4):289-94.

9. Shankar A, Dracham C, Ghoshal S, Grover S. Prevalence of depression and anxiety disorder in cancer patients: An institutional experience. Indian J Cancer. 2016;53(3):432-4.

10. Amirifard N, Payandeh M, Aeinfar M, Sadeghi M, Ghafarpor S. A Survey on the Relationship between Emotional Intelligence and Level of Depression and Anxiety among Women with. Breast Cancer. 2017;11(1):54-7.

11. Thomas BC, Devi N, Sarita GP, Rita K, Ramdas K, Hussain BM, et al. Reliability and validity of the Malayalam hospital anxiety and depression scale (HADS) in cancer patients. Indian J Med Res. 2005;122(5):395-9.

12. Cuthbert CA, Moules N. The application of qualitative research findings to oncology nursing practice. Oncol Nurs Forum. 2014;41(6):683-5.

13. Mykletun A, Stordal E, Dahl AA. Hospital Anxiety and Depression (HAD) scale: factor structure, item analyses and internal consistency in a large population. Br J Psychiatry. 2001;179:540-4.

14. Smith AB, Selby PJ, Velikova G, Stark D, Wright EP, Gould A, et al. Factor analysis of the Hospital Anxiety and Depression Scale from a large cancer population. Psychol Psychother. 2002;75(Pt 2):165-76.

15. Kotsakis A, Georgoulias V. Avelumab, an anti-PD-L1 monoclonal antibody, shows activity in various tumour types. Lancet Oncol. 2017;18(5):556-7.

16. Jiao Q, Ren Y, Ariston Gabrie AN, Wang Q, Wang Y, Du L, et al. Advances of immune checkpoints in colorectal cancer treatment. Biomed Pharmacother. 2020;123:109745.

17. Massie MJ. Prevalence of depression in patients with cancer. J Natl Cancer Inst Monogr. 2004(32):57-71.

18. Grassi L, Caruso R, Nanni MG. Somatization and somatic symptom presentation in cancer: a neglected area. Int Rev Psychiatry. 2013;25(1):41-51.

19. Myers G. Immune-related adverse events of immune checkpoint inhibitors: a brief review. Curr Oncol. 2018;25(5):3427. 